OPEN ACCESS

Edited by:

Gang Rao,

Zhejiang University, China

Reviewed by:

Yiquan Li,

Nanjing University, China

Yan $\mathrm{Hu}$,

University of Science and Technology of China, China

*Correspondence:

Yujiang $L$

toleeyj@gmail.com

Huiping Zhang

huiping@ies.ac.cn

Specialty section:

This article was submitted to Structural Geology and Tectonics,

a section of the journal

Frontiers in Earth Science

Received: 28 July 2020

Accepted: 16 October 2020

Published: 13 November 2020

Citation:

Li Y, Zhang H, Tang L, Chen L and Jing $Y$ (2020) Seismogenic Faulting of the 2016 Mw 6.0 Hutubi Earthquake in the Northern Tien Shan Region: Constraints From Near-Field Borehole Strain Step Observations and

Numerical Simulations.

Front. Earth Sci. 8:588304. doi: 10.3389/feart.2020.588304

\section{Seismogenic Faulting of the 2016 Mw 6.0 Hutubi Earthquake in the Northern Tien Shan Region: Constraints From Near-Field Borehole Strain Step Observations and Numerical Simulations}

\author{
Yujiang $\mathrm{Li}^{1 *}$, Huiping Zhang ${ }^{2 *}$, Lei Tang ${ }^{1}$, Lianwang Chen ${ }^{1}$ and Yan Jing ${ }^{1}$ \\ ${ }^{1}$ National Institute of Natural Hazards, Ministry of Emergency Management, Beijing, China, ${ }^{2}$ State Key Laboratory of Earthquake \\ Dynamics, Institute of Geology, China Earthquake Administration, Beijing, China
}

Constraining the seismotectonic faulting that occurred as a result of the $2016 \mathrm{Mw} 6.0$ Hutubi earthquake provides valuable information about the deformation in the northern Tien Shan region. However, due to the lack of surface rupturing and high quality near-field teleseismic data, the exact nature of the faulting remains controversial. In our study, we analyze the coseismic strain time series of the Mw 6.0 Hutubi earthquake using strain data collected from nearby borehole stations. The tensile and compressive coseismic strain steps account for most of the recorded borehole data in this region. Employing a numerical model that is based on elastic dislocation theory, we reproduce the observed tensile and compressive coseismic strain steps using source parameters that were generated through seismic wave inversion, seismic reflection data, and aftershock relocation. By conducting a comparative analysis between the predicted and observed coseismic strain steps, we study the seismogenic faulting of the Mw 6.0 Hutubi earthquake. The results indicate that when the source parameters are $292^{\circ} / 62^{\circ} / 80^{\circ}$ (strike/dip/rake), the predicted tensile and compressive characteristics for 13/16 channels are consistent with the observational data. Based on these results, we infer that the seismogenic faulting, which is located near the Horgos-Manas-Tugulu fault, can be characterized as a high-angle blind back-thrust fault with a north-dipping fault plane. Providing constraints on the seismogenic faulting associated with the $2016 \mathrm{Mw}$ 6.0 Hutubi earthquake also yields to understand the mechanism of the overall deformation pattern in the northern Tien Shan region.

\footnotetext{
Keywords: northern Tien Shan, coseismic strain step, seismogenic faulting, elastic dislocation theory, Mw 6.0 Hutubi earthquake
}

\section{INTRODUCTION}

On December 8, 2016, the Mw 6.0 Hutubi earthquake occurred within the active fold-and-thrust belts of the northern Tien Shan foreland basin, northwestern China (Li et al., 2018; Lu et al., 2018). However, as the absence of coseismic surface rupturing and high-quality far-field seismic observation record, the seismogenic faulting of this earthquake remains controversial. 
In previous work, this earthquake fault has been described as either a low-angle south-dipping thrust fault or a high-angle north-dipping back-thrust fault (Liu et al., 2017; Liu et al., 2018; Lu et al., 2018; Gong et al., 2019; Wang et al., 2019; Xu et al., 2019; Yang et al., 2019). From seismic reflection data and seismic wave inversion results, it is postulated that the mainshock is controlled by a large-scale south-dipping thrust fault, while the aftershocks relocation results indicate the presence of a secondary back-thrust fault (Lu et al., 2018; Yang et al., 2018). However, the aftershock relocation suggests that this seismogenic faulting is a northdipping secondary fault (Liu et al., 2018; Xu et al., 2019).

Earthquakes transfer stress to the surrounding rock, which can cause observable changes in geodetic data (Nykolaishen et al., 2015). Borehole strain observations record robust coseismic deformation information that not only provide constraints for the tensile and compressive coseismic stress and strains (Gladwin et al., 1994; Linde et al., 1996; Qiu and Shi, 2003; Johnston et al., 2006; Qiu et al., 2013; Barbour et al., 2015; Gong et al., 2019), but they can also act as parameters in numerical simulations of fault geometry. Using the observed four-component borehole strain data at the Changping station, Qiu and Shi (2003) analyzed the coseismic strain steps and estimated the corresponding stress changes induced by two Zhangbei earthquakes. By quantifying spatial differences in the borehole strain data that captured changes created by the 2004 Kii peninsular earthquakes, Asai et al. (2005) determined the coseismic strain steps in the Nankai Trough. Barbour et al. (2015) employed the data recorded on nine borehole strainmeters to characterize the coseismic strain caused by earthquakes with a range of magnitudes and distances. Based on the static-dynamic strain response of the area affected by the Mw 6.0 Hutubi earthquake, Gong et al. (2019) identified four stations where the borehole data capture resolvable static strain changes.

In order to analyze and characterize the coseismic strain step that was created by the Mw 6.0 Hutubi earthquake, we collected data from four near-field four-component borehole strainmeters that reside in observational stations located throughout the northern Tien Shan region. Based on elastic dislocation theory (Okada, 1985), we calculated the coseismic stress field using the different sets of source parameters that were inferred via seismic wave inversion, seismic reflection data, and aftershock relocation. After using these source parameters to generate synthetic strain step data, we then constrained the seismogenic faulting of the $\mathrm{Mw}$ 6.0 Hutubi earthquake by identifying the source parameters that

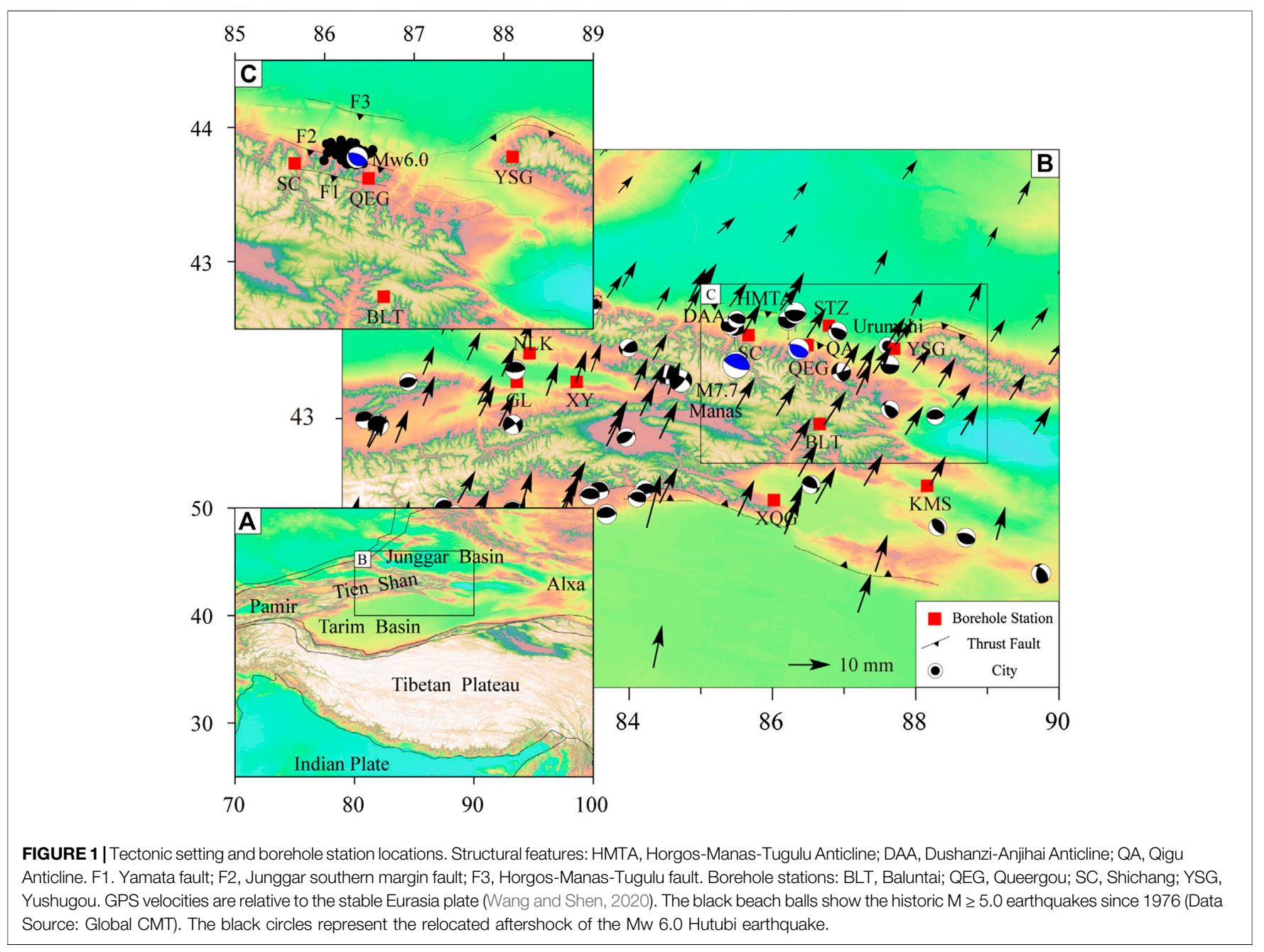


minimized the difference between the predicted and observed tensile and compressive coseismic strain steps.

\section{TECTONIC SETTING}

The Tien Shan orogenic belt is bounded by the Tarim Basin to the south and the Junggar Basin to the north (Figure 1) (Zhang et al., 2003). As one of the largest orogenic belts within the Asian continent, this region was formed by multiple instances of plate collision and subduction (Xiao et al., 2004; Charvet et al., 2011; Chen et al., 2014; Qiu et al., 2019). Since the Cenozoic, the Tien Shan tectonic zone has experienced strong shortening and uplift due to continued convergence between the Indian and Eurasian plates (Molnar and Tapponnier, 1975; Allen et al., 1999; Qiu et al., 2019; Zhou et al., 2020); this ongoing collision has both created new faults and reactivated old faults (Yin et al., 1998). GPS data indicates that the crustal shortening rate in the Tien Shan tectonic zone increases from $\sim 5-10 \mathrm{~mm} / \mathrm{yr}$ in the east to $\sim 20 \mathrm{~mm} / \mathrm{yr}$ in the west (Yang et al., 2008; Liu et al., 2016). Deep seismic reflection profiles have revealed the thin-skinned tectonics of the crust beneath the northern Tien Shan piedmont, which consists of
TABLE 1 | Basic data of the borehole stations

\begin{tabular}{lcccll}
\hline Stat. & Lon/ & Lat ${ }^{\circ}$ & Borehole depth /m & Lithology & \multicolumn{1}{c}{ Fault } \\
\hline QEG & 86.49 & 43.82 & 122 & Sandstone & Southern Junggar fault \\
SC & 85.67 & 43.93 & 84 & Glutenite & Southern Junggar fault \\
BLT & 86.66 & 42.94 & 157 & Sandstone & Borokonu fault \\
YSG & 87.70 & 43.78 & 35 & Sandstone & Northern Bogda fault
\end{tabular}

(from south to north) the piedmont Qigu fold-and-thrust zone, the Horgos-Manas-Tugulu active fold-and-thrust zone, and the Dushanzi-Anjihai active fold-and-thrust zone (Zhang et al., 1994; Yang et al., 2013; Gong et al., 2019). These active reverse fault-fold zones are the primary causes of the frequent seismicity in this region (Avouac et al., 1993; Zhang et al., 1996; Deng et al., 2000; Wang et al., 2004).

In 2016, the Mw 6.0 Hutubi earthquake occurred in the active fold-and-thrust belt of the northern Tien Shan foreland basin. This region has accommodated $\sim 50 \%$ of the predicted crustal shortening (Yin et al., 1998; Zubovich et al., 2010; Yang et al., 2019). Seismic reflection profiles indicated that the seismogenic faulting created by the Mw 6.0 Hutubi earthquake is closely

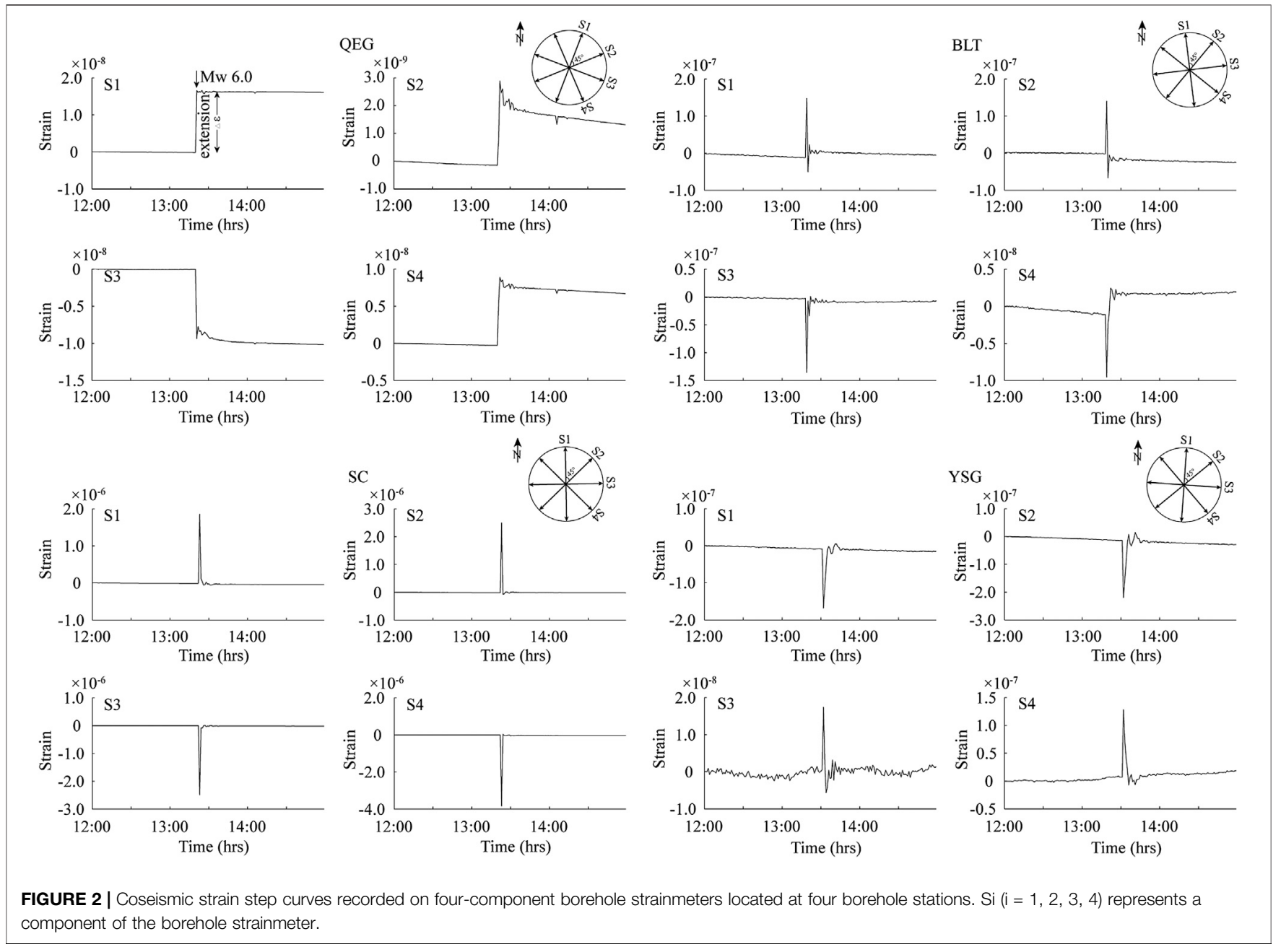


TABLE 2 | Observed coseismic strain step characteristics

\begin{tabular}{|c|c|c|c|c|c|c|c|c|c|c|c|c|c|}
\hline \multirow[t]{2}{*}{ Stat. } & \multirow{2}{*}{$\begin{array}{c}\text { Epicenter } \\
\text { distance/km }\end{array}$} & \multicolumn{4}{|c|}{ Component azimuth $/^{\circ}$} & \multicolumn{4}{|c|}{ Coseismic strain step $/ 10^{-10}$} & \multicolumn{4}{|c|}{ extension or compression } \\
\hline & & 1 & 2 & 3 & 4 & 1 & 2 & 3 & 4 & 1 & 2 & 3 & 4 \\
\hline QEG & 11 & 21 & 66 & 111 & 156 & 164 & 24 & -89 & 84 & + & + & - & + \\
\hline SC & 54 & -7 & 38 & 83 & 128 & -235 & 56 & -145 & -341 & - & + & - & - \\
\hline $\mathrm{BLT}$ & 107 & -1 & 44 & 89 & 134 & 178 & -124 & -42 & 245 & + & - & - & + \\
\hline YSG & 110 & 4 & 49 & 94 & 139 & -18 & -36 & 7 & 16 & - & - & + & + \\
\hline
\end{tabular}

In the table, the azimuth of component is defined as zero in the north direction, and the clockwise rotation is positive; 1 to 4 represent the four components; ' + ' and '-' represent tensile and compressive strain, respectively, and tensile strain is considered as positive.

TABLE 3 | Compilation of the source parameters of the Mw 6.0 Hutubi earthquake from different data types

\begin{tabular}{|c|c|c|c|c|c|c|c|}
\hline \multirow[t]{2}{*}{ Source* $^{\star}$} & \multicolumn{2}{|c|}{ Epicenter $\left({ }^{\circ}\right)$} & \multicolumn{3}{|c|}{ Focal mechanism solution } & \multirow[t]{2}{*}{ Depth (km) } & \multirow[t]{2}{*}{ Sets } \\
\hline & Lon. & Lat. & Strike $\left({ }^{\circ}\right)$ & Dip ( ) & Rake ( $\left.{ }^{\circ}\right)$ & & \\
\hline \multicolumn{8}{|l|}{ Fault dipping: South } \\
\hline Lu et al. (2018) & 86.350 & 43.830 & 91 & 22 & 90 & 16 & Model 1 \\
\hline Yang et al. (2018) & 86.380 & 43.770 & 113 & 26 & 77 & 15.2 & \\
\hline \multicolumn{8}{|l|}{ Fault dipping: North } \\
\hline Xu et al. (2019) & 86.350 & 43.830 & 271 & 64 & 90 & 21 & Model 2 \\
\hline Yang et al. (2019) & 86.345 & 43.823 & 264 & 28.8 & 90 & 17 & \\
\hline Liu et al. (2018) & 86.363 & 43.776 & 292 & 62 & 80 & 17 & Model 3 \\
\hline
\end{tabular}

related to the south-dipping Horgos-Manas-Hutubi fault (Lu et al., 2018). However, an aftershock relocation analysis provides support for the hypothesis that this earthquake occurred on a north-dipping back-thrust fault that exhibits the 'y-type' distribution with the main rupture plane of the 1906 Manas earthquake (Lu et al., 2018). If this is true, then this fold-type earthquake was caused by the continuous stress accumulation that arose during the ongoing collision between the Tien Shan region and the Junggar Basin (Liu et al., 2018).

\section{DATA}

It has been repeatedly demonstrated that four-component borehole strainmeters yield high-quality and high-precision $\left(10^{-10}\right)$ recordings of the static and dynamic strains caused by earthquakes (Qiu and Shi, 2003; Ouyang et al., 2004; Qiu et al., 2013; Gong et al., 2019). To better monitor the ongoing crustal deformation in this area and to explore the relationship between borehole coseismic strain steps and strong earthquakes, we deployed eleven RZB-type four-component borehole strainmeters in the northern Tien Shan region since 2015.

In this paper, we analyzed the tensile and compressive coseismic strain steps recorded at stations QEG, SC, BLT, and YSG. All four strainmeters were installed directly into the bedrock of the southern Junggar thrust fault, the Borokonu strike-slip fault, and thrust fault located along the northern margin of Bogda Mountain at depths of 35-157 m (Table 1).

The coseismic strain steps and subsequent changes recorded at stations QEG, SC, BLT, and YSG are shown in Figure 2. According to the definition of a tensional or compressional coseismic strain step (Qiu and Shi, 2003), the coseismic strain step is tensional when the step change $\Delta \varepsilon>0$, as shown in the $S 1$

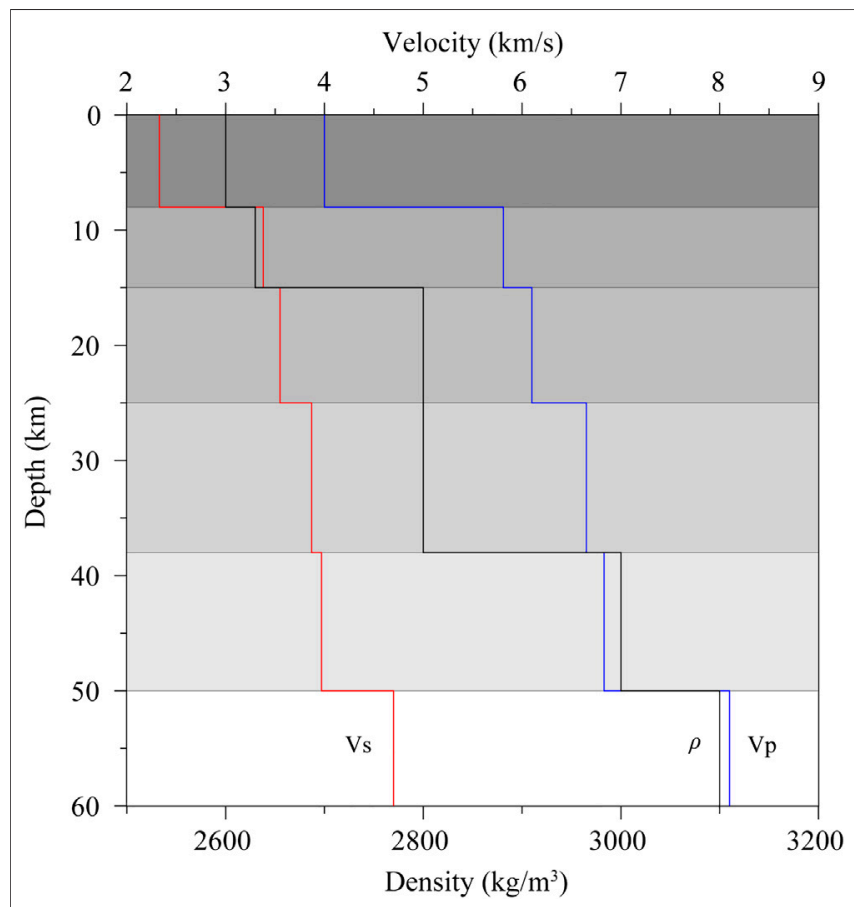

FIGURE 3 | Parameters of the stratified medium model. Vp represents the P-wave seismic velocity, Vs represents the S-wave velocity, $\rho$ represents the lithospheric density.

component of the QEG observation station (Figure 2). The maximum tensile and compressive changes of the coseismic strain steps observed at stations QEG, SC, BLT, and YSG reach values of $1.6 \times 10^{-8},-3.4 \times 10^{-8}, 2.5 \times 10^{-8}$, and $-3.6 \times$ $10^{-9}$, respectively (Figure 2; Table 2 ). 


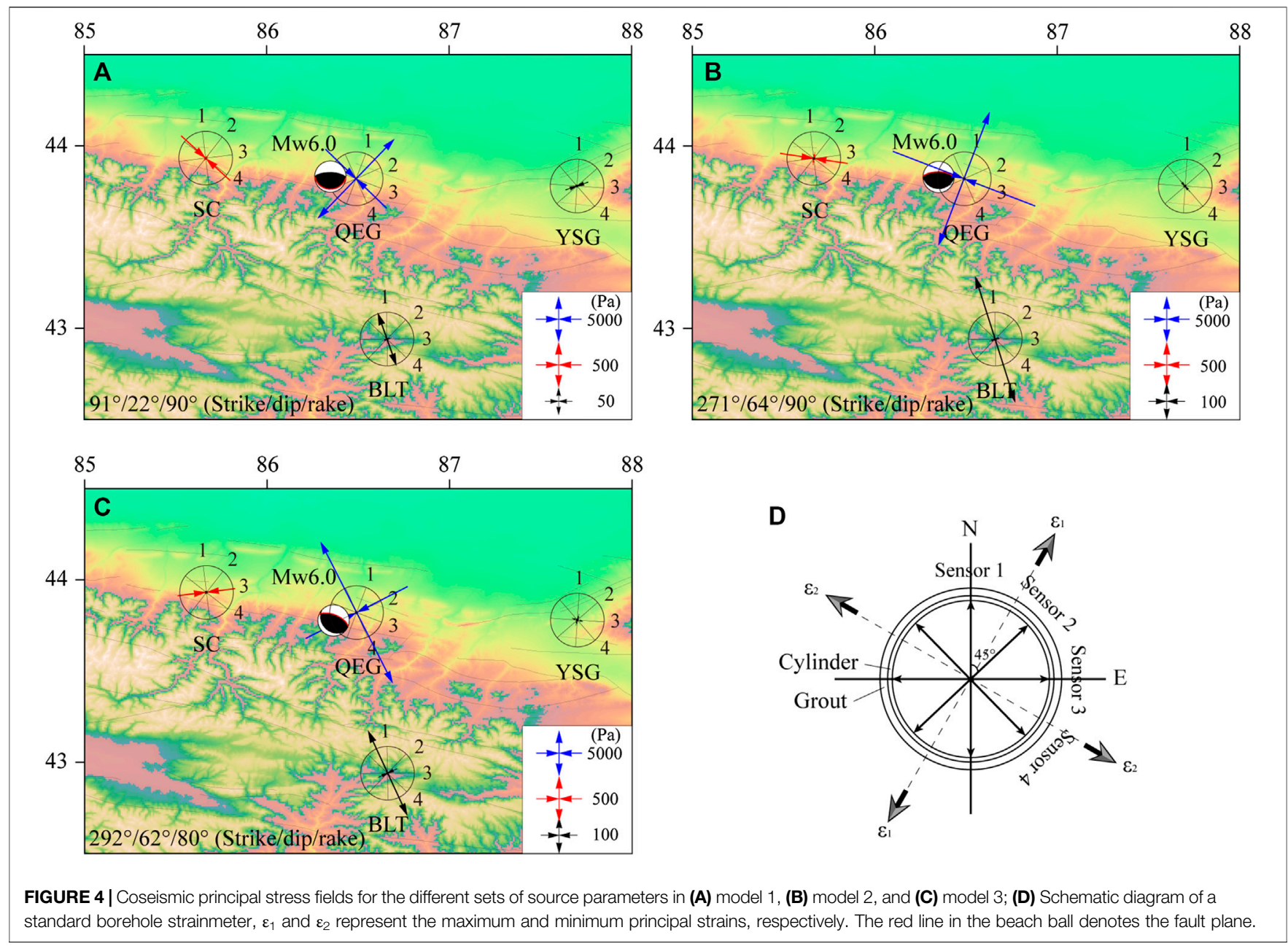

\section{MODELS AND METHODS}

The source parameters of the Mw 6.0 Hutubi earthquake, according to the published seismic wave, artificial seismic reflection profiles, and aftershocks relocation studies are summarized in Table 3. Where there is a consensus on the strike and rake of the seismogenic fault (all are oriented nearly E-W), there are contradictory characterizations of the fault's dip angle as either a south-dipping large-scale thrust fault or a north-dipping secondary back-thrust fault (Liu et al., 2018; Lu et al., 2018; Xu et al., 2019).
For the slip model, InSAR observations reveal that the slip distributions are dominated by a nearly pure-thrust fault with no apparent surface rupture, a rupture length of $20 \mathrm{~km}$, and peak slip values ranging from $\sim 0.1 \mathrm{~m}$ to $0.56 \mathrm{~m}$ at depths of $12-18 \mathrm{~km}$ (Liu et al., 2017; Wang et al., 2019; Yang et al., 2019). According to these published inversion results, we determined that the rupture length, rupture width, and average slip magnitude are $20 \mathrm{~km}, 15 \mathrm{~km}$, and $0.1 \mathrm{~m}$, respectively. Furthermore, we characterized the seismogenic fault as a blind thrust fault (Lu et al., 2018; Wang et al., 2019; Yang et al., 2019) with a fault tipline at a depth of $7.5 \mathrm{~km}$.

TABLE 4 | Comparison of the predicted and observed tensile and compressive characteristics of the coseismic strain steps

\begin{tabular}{|c|c|c|c|c|c|c|c|c|c|c|c|c|c|c|c|c|c|}
\hline \multirow[b]{2}{*}{ Characteristics } & \multicolumn{4}{|c|}{ BLT } & \multicolumn{4}{|c|}{ SC } & \multicolumn{4}{|c|}{ QEG } & \multicolumn{4}{|c|}{ YSG } & \multirow[t]{2}{*}{ Consistency } \\
\hline & 1 & 2 & 3 & 4 & 1 & 2 & 3 & 4 & 1 & 2 & 3 & 4 & 1 & 2 & 3 & 4 & \\
\hline Observed & + & - & - & + & - & + & - & - & + & + & - & + & - & - & + & + & \\
\hline Model 1 & + & - & - & + & - & - & - & - & + & + & + & - & + & - & - & + & $11 / 16$ \\
\hline Model 2 & + & - & - & + & - & - & - & - & - & - & - & + & - & + & - & - & $10 / 16$ \\
\hline Model 3 & + & - & - & + & - & - & - & - & + & - & + & + & - & - & + & + & $13 / 16$ \\
\hline
\end{tabular}

'+' and '-' represent tensile and compressive coseismic strain steps, respectively. 


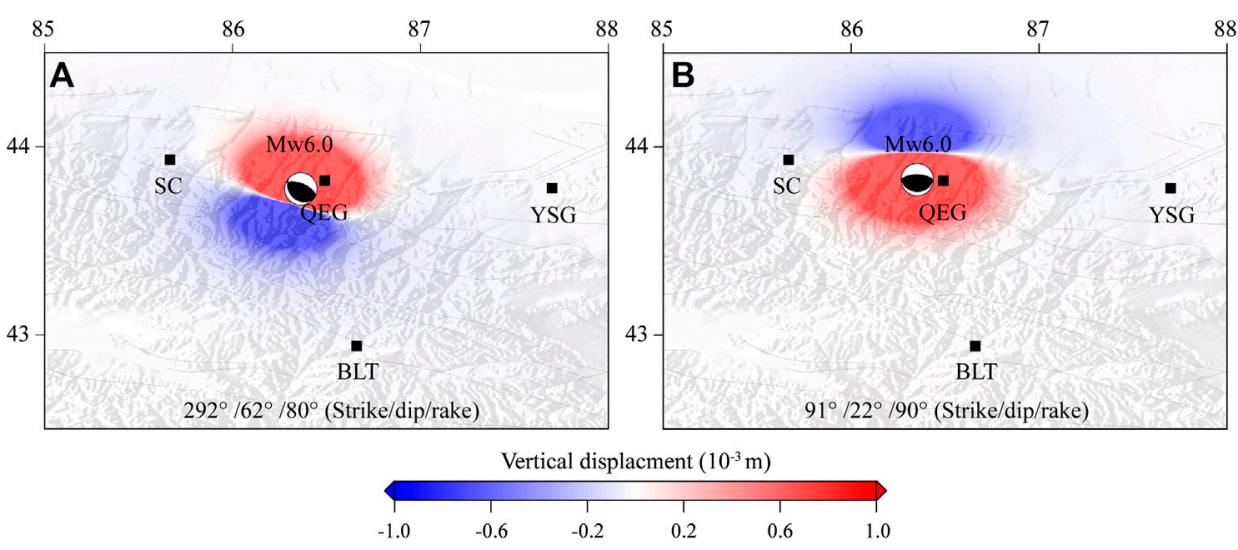

FIGURE 5 | Vertical coseismic displacement field for different sets of source parameters. The red line in the beach ball denotes the fault plane.

Based on the depth profiles of converted waves from earthquakes in the northern Tien Shan region (Shao et al., 1996), we determined the parameters necessary for our stratified model (Figure 3). By employing PSGRN/PSCMP (Wang et al., 2006), a program that consists of a dislocation source model embedded in a mixed elastic/inelastic layered halfspace, we generated six independent stress tensors based on the three different sets of source parameter values for the fault strike, dip, and rake (Table 3). Then we calculated the principal stresses and the direction cosines from the eigenvalues and the eigenvectors of the stress tensors, respectively. From this data, we quantified the stress fields at the four borehole stations.

\section{RESULTS}

\section{Characteristics of the Coseismic Principal Stress Field}

Figure 4 shows the characteristic coseismic principal stress field for the three different sets of source parameters. In model 1, the orientations of the maximum horizontal

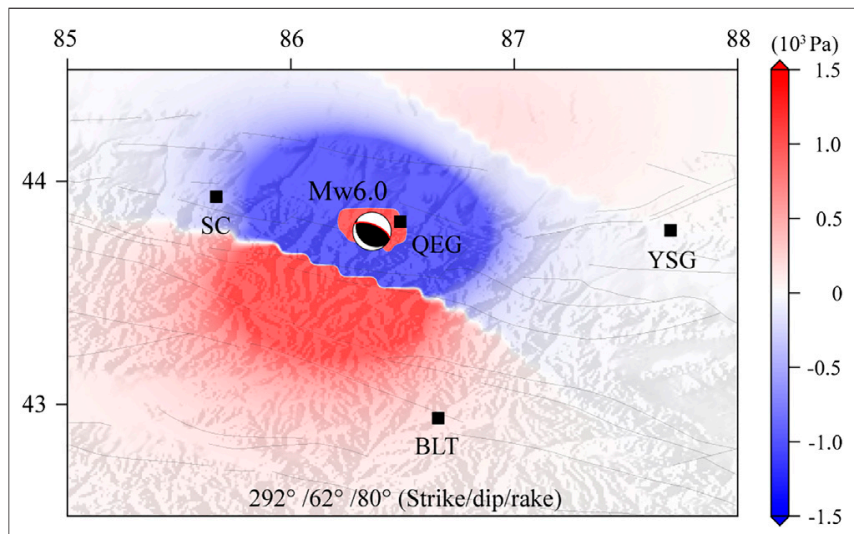

FIGURE 6 | The coseismic maximum principal stress field. Positive values represent tensile stresses, and negative values represent compressive stresses. The red line in the beach ball denotes the fault plane. principal compressive stress at the QEG, SC, YSG, and BLT observation stations are NW-SE, NW-SE, NEE-SWW, and NEE-SWW, respectively. In model 2, the orientations of the maximum horizontal principal compressive stress at the QEG, SC, YSG, and BLT observation stations are NWW-SEE, nearly E-W, NW-SE, and NEE-SWW, respectively. In model 3 , the orientations of the maximum horizontal principal compressive stress at the QEG, SC, YSG, and BLT observation stations are NE-SW, nearly E-W, NNE-SSW, and NEE-SWW, respectively.

\section{Characteristics of the Coseismic Strain Field}

By combining the maximum coseismic principal stress field and the known azimuths of the four components of the borehole strainmeters (Table 2), we quantified the tensile and compressive

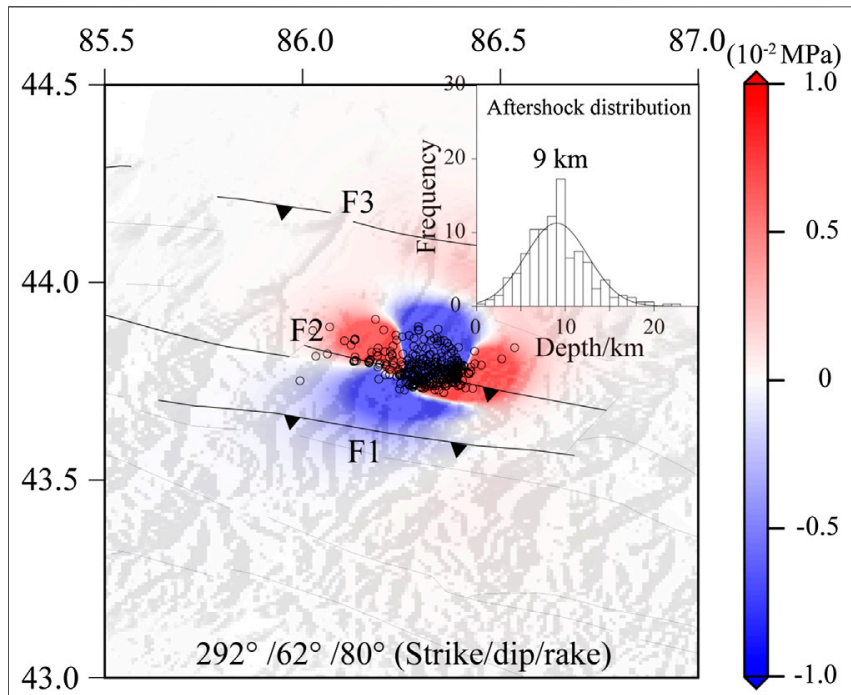

FIGURE 7 | Coseismic Coulomb stress change for the best-fit source parameters of $292^{\circ} / 62^{\circ} / 80^{\circ}$ (strike/dip/rake). The frictional coefficient is assumed to be 0.4 (King et al., 1994). Fault labels are the same as in Figure 1. 
characteristics of the coseismic strain steps (Table 4) and compared those results to the coseismic steps recorded at the borehole stations (Table 2). In model 1, the predicted tensile and compressive step characteristics match the observed step characteristics on 11/16 channels. In model 2, the predicted tensile and compressive step characteristics match the observed step characteristics on 10/16 channels. In model 3, the predicted tensile and compressive characteristics match the observed step characteristics on 13/16 channels (Table 4). Based on our analysis, we conclude source parameters of $292^{\circ} / 62^{\circ} / 80^{\circ}$ (strike/dip/rake) best reproduce the observed strain steps, suggesting that the Mw 6.0 Hutubi earthquake seismogenic fault is a north-dipping high-angle blind thrust fault.

\section{DISCUSSION}

Near-field geodetic observations provide the basic data necessary to characterize coseismic deformation (Johnston et al., 2006; Nykolaishen et al., 2015) and numerically simulate both the fault rupture plane and earthquake-induced deformation (Shen et al., 2009; Jiang et al., 2020).

\section{Reliability Analysis of the Results}

Our observed tensile and compressive coseismic strain steps are consistent with those in published studies (Gong et al., 2019). To validate the reliability of our simulation results, we calculated the coseismic vertical displacement field, the maximum principal

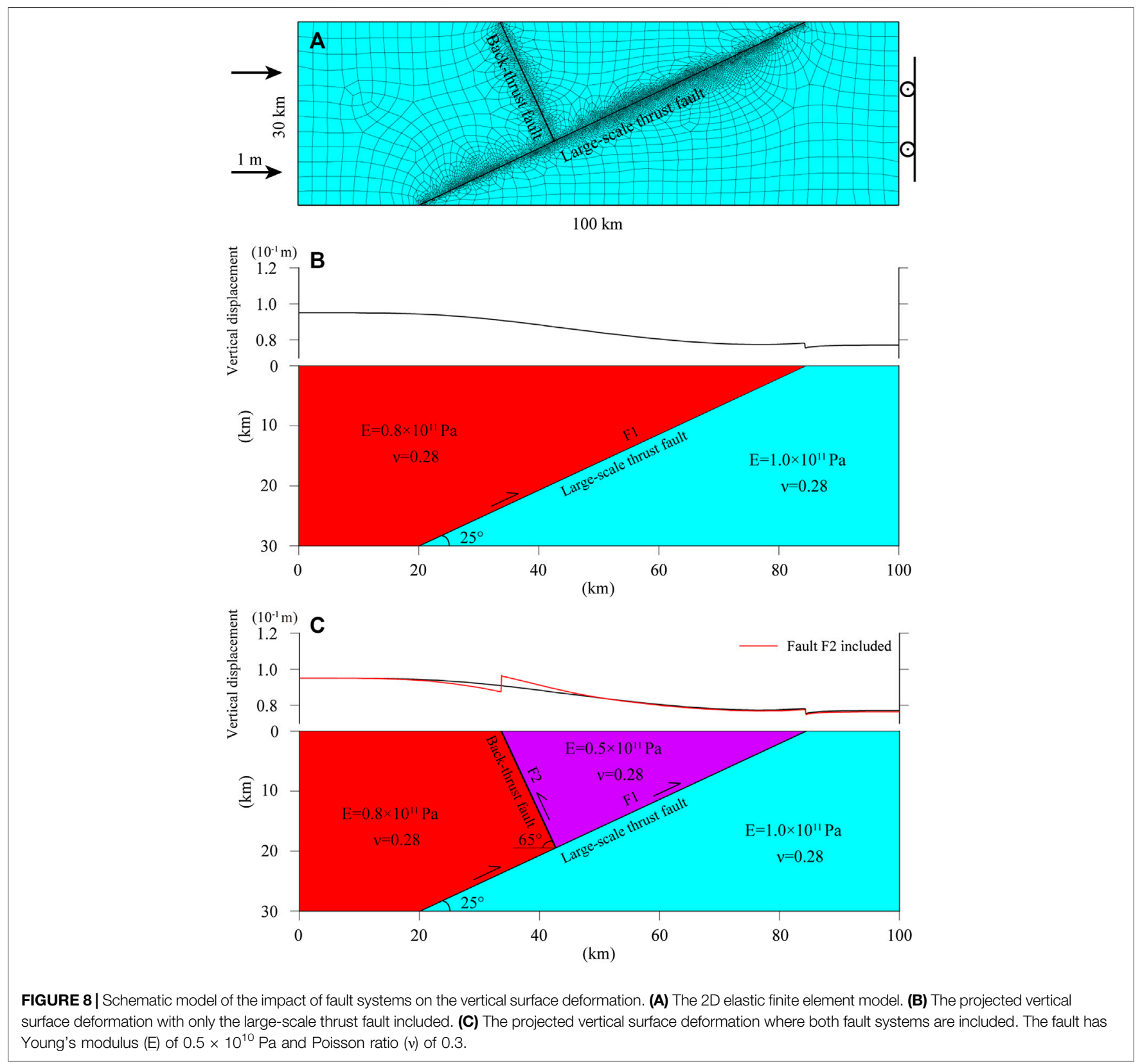


stress field at the surface, and relations between the Coulomb stress change caused by the mainshock for the best-fit source parameters and aftershocks distribution. The coseismic vertical displacement field shows that when the seismogenic fault experienced bilateral rupturing, the hanging wall exhibited coseismic vertical uplift while the footwall exhibited coseismic subsidence (Figure 5). The projected hanging wall displacement is greater than that of the footwall (Figure 5A); these displacement patterns are consistent with those inferred from cross-fault profiles based on InSAR observations (Wang et al., 2019; Yang et al., 2019). When the fault plane dips to the south, the modeled vertical coseismic displacement is a poor fit for the InSAR observations (Figure 5B). From these results, we conclude that the seismogenic fault is a north-dipping thrust fault.

The maximum principal stress field shows that the coseismic stress changes are relatively large at stations QEG, SC, and BLT, while the changes recorded at station YSG are relatively small (Figure 6). These coseismic stress changes are consistent with the observed coseismic strain steps (Table 2), and we attribute the spatial variation in the observed borehole strains to the heterogeneity of the coseismic stress changes.

Using the aftershocks relocation depths (Xu et al., 2019) in conjunction with the best-fit source parameters, we determined that the static coseismic Coulomb stress change at the two ends of the rupture plane at a depth of $9 \mathrm{~km}$ exceeds $0.01 \mathrm{MPa}$, suggesting that the mainshock hastens or triggers the aftershocks (Figure 7). However, for some aftershocks that occurred on or near the rupture plane, this seemingly contradictory relation may be driven by afterslip (Ross et al., 2017; Perfettini et al., 2019). This observation is consistent with the findings of Wang et al. (2019) and provides further support for the theory that the seismogenic fault generated by the Mw 6.0 Hutubi earthquake is a north-dipping blind thrust fault.

\section{Tectonic Implications}

Due to compression caused by the collision of the NS-trending Indian plate and the rigid Junggar Basin, the zone between the northern Tien Shan and the Junggar Basin contains many foldand-thrust structures (Burchfiel et al., 1999; Deng et al., 1999), including listric south-dipping thrust faults and a set of northdipping high-angle back-thrust faults at the Frontier of the nappe (Liu et al., 2007; Guan et al., 2016). Similar to the categorization of the seismogenic Horgos-Manas-Tugulu fault of the $1906 \mathrm{Mw} 7.7$ Manas earthquake as a large-scale listric thrust fault (Zhang et al., 1994; Wang et al., 2004), structural studies indicate that the back-thrust faults related to the anticline located in the fold belts near the Hutubi earthquake epicenter are all blind thrust faults (Chen et al., 2007; Lu et al., 2018). Modeling results indicate that the continued IndiaEurasia collision resulted in the reactivation of the Tien Shan mountain range and its related fault system (Neil and Houseman, 1997; Li et al., 2018); the Mw 6.0 Hutubi earthquake occurred on a reactivated rift-related structure that is connected to the Horgos-Manas-Tugulu thrust fault.

Double-difference relocation of the aftershocks demonstrate that the Hutubi earthquake seismogenic fault, as a north-dipping blind back-thrust fault that has a thrust direction that opposes the general sense of thrust in the piedmont thrust nappe of the northern Tien Shan, is located near the Horgos-Manas-Tugulu fault (Liu et al., 2018; Xu et al., 2019). This analysis is essentially consistent with our findings where the north-dipping fault plane generates a coseismic principal stress field that generates the observed changes in the near-field coseismic tensile and compressive strain steps. Thus, it is likely that the Hutubi earthquake seismogenic fault is a high-angle blind back-thrust fault with a north-dipping fault plane.

A back-thrust fault, which can rupture independently (Chuang et al., 2014; He et al., 2018), is regarded as a secondary structure in the thrust nappe tectonic belt (Stagpoole and Nicol, 2008; Xu et al., 2015; Zelilidis et al., 2016; Martinod et al., 2020). Based on the occurrence of the 1906 Mw 7.7 Manas earthquake and the 2016 Mw 6.0 Hutubi earthquake, we conclude that the Late Cenozoic crustal deformation caused by the continuous collision between

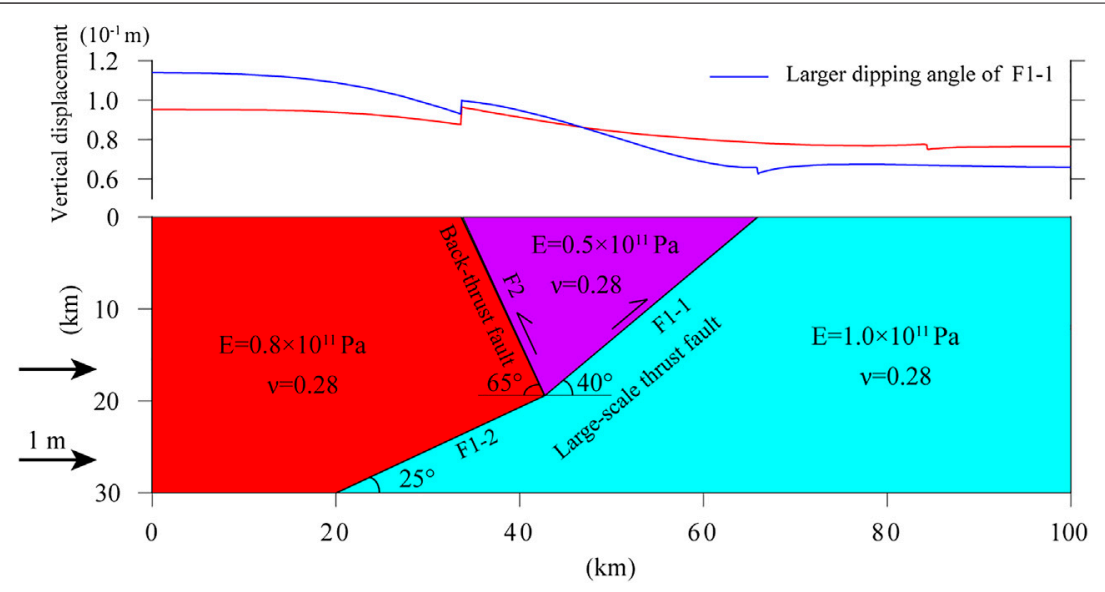

FIGURE 9 | Impact of fault dipping angle change on the vertical surface deformation. The red line in the upper panel represents the same vertical displacement as in Figure 8C. 
Indian and Eurasia plates was accommodated by slip on the Horgos-Manas-Tugulu thrust fault and also on the secondary back-thrust faults.

In order to analyze the influence of the secondary back-thrust fault on crustal deformation, we employ the ANSYS commercial software to construct a two-dimensional elastic finite element model (Figure 8A). The model includes the lateral heterogeneity, the large-scale thrust fault, and the secondary back-thrust fault. The fault geometry and regional properties are referred to the previous studies (Wang et al., 2004; Liu et al., 2018). First, we model the vertical deformation with only the large-scale fault included (Figure 8B); then we analyze the influence of the backthrust fault on vertical deformation. As shown by the modeled vertical surface displacement in Figure 8C, this back-thrust fault contributes to the significant uplift observed in this region.

Furthermore, with the dip angle of the large-scale thrust fault increasing from the deep to the shallow, this geometry change inhibits the slip on the thrust fault (Bilham and England, 2001) and benefits the strain energy accumulation on the back-thrust faults (Figure 9) (Xu et al., 2015; Zhang et al., 2019), although this process is influenced by other factors such as confining pressure, fault frictional coefficient and rheological property (Neil and Houseman, 1997; Collettini et al., 2019). The two fault systems jointly absorbed or facilitated the crustal shortening (Zubovich et al., 2010; Poblet and Lisle, 2011) and are responsible for the present-day uplift of the northern Tien Shan region that expressed as a 'pop-up' structure.

\section{CONCLUSION}

In this paper, we used the near-field borehole data to analyze the tensile and compressive characteristics of the coseismic strain steps for the Mw 6.0 Hutubi earthquake. After constructing a model based on elastic dislocation theory, we simulated the coseismic strain step characteristics for three different sets of source parameters. Our model results indicate that when the seismogenic fault source parameters are $292^{\circ} / 62^{\circ} / 80^{\circ}$ (strike/dip/ slip), the predicted and observed tensile and compressive characteristics of the coseismic strain steps are fairly consistent with one another. With these source parameters, the Hutubi earthquake is likely a high-angle blind back-thrust fault with a north-dipping fault plane. Based on additional data, we inferred

\section{REFERENCES}

Allen, M. B., Vincent, S. J., and Wheeler, P. J. (1999). Late Cenozoic tectonics of the Kepingtage thrust zone: interactions of the Tien Shan and Tarim Basin, northwest China. Tectonics 18, 639-654. doi:10.1029/ 1999 tc900019

Asai, Y., Okubo, M., Ishii, H., Aoki, H., Yamauchi, T., Kitagawa, Y., et al. (2005). Co-seismic strain-steps associated with the 2004 off the Kii peninsula earthquakes-Observed with Ishii-type borehole strainmeters and quartztube extensometers. Earth Planets Space. 57, 309-314. doi:10.1186/ bf03352568

Avouac, J. P., Tapponnier, P., Bai, M., You, H., and Wang, G. (1993). Active thrusting and folding along the northern Tien Shan and late Cenozoic rotation that this seismogenic fault is located near the Horgos-ManasTugulu thrust fault, which is the seismogenic fault of the $1906 \mathrm{Mw}$ 7.7 Manas earthquake.

Our results, which are informed by both near-field borehole strain observational data and numerical simulations, provide new insight into the analysis of the geometry of seismogenic fault. With more high-quality geodetic and seismic data, it may be possible to elucidate the seismotectonic and tectonic deformation of the northern Tien Shan region using high-resolution threedimensional models.

\section{DATA AVAILABILITY STATEMENT}

The raw data supporting the conclusions of this article will be made available by the authors, without undue reservation.

\section{AUTHOR CONTRIBUTIONS}

YL: Conceptualization, Methodology, Software, Visualization, Formal analysis, Writing-Original draft. HZ: Conceptualization, Methodology, Writing-Reviewing and Editing. LT: Methodology, Formal analysis, Investigation. LC: Methodology, Writing-Reviewing and Editing. YJ: Methodology, Data curation.

\section{FUNDING}

This work was jointly supported by the National Natural Science Foundation of China (Grant Nos. 41874116, 41574081), the Research Grant from the Institute of Crustal Dynamics, China Earthquake Administration (No. ZDJ2019-16).

\section{ACKNOWLEDGMENTS}

We appreciate Renqi Lu for providing the seismotectonic model of the Hutubi earthquake and Shanshan Liang for the relocated aftershocks. We thank LetPub (www.letpub.com) for its linguistic assistance during the preparation of this manuscript. Figures were plotted using the Generic Mapping Tools (Wessel et al., 2013).

of the Tarim relative to Dzungaria and Kazakhstan. J. Geophys. Res. 98, 6755-6804. doi:10.1029/92jb01963

Barbour, A. J., Agnew, D. C., and Wyatt, F. K. (2015). Coseismic strains on plate boundary observatory borehole strainmeters in southern California. Bull. Seismol. Soc. Am. 105, 431-444. doi:10.1785/0120140199

Bilham, R., and England, P. (2001). Plateau 'pop-up' in the great 1897 Assam earthquake. Nature 410, 806-809. doi:10.1038/35071057

Burchfiel, B. C., Brown, E. T., Qidong, D., Xianyue, F., Jun, L., Molnar, P., et al. (1999). Crustal shortening on the margins of the Tien Shan, Xinjiang, China. Int. Geol. Rev. 41, 665-700. doi:10.1080/ 00206819909465164

Charvet, J., Shu, L., Laurent-Charvet, S., Wang, B., Faure, M., Cluzel, D., et al. (2011). Palaeozoic tectonic evolution of the Tianshan belt, NW China. Sci. China Earth Sci. 54, 166-184. doi:10.1007/s11430-010-4138-1 
Chen, K., Gumiaux, C., Augier, R., Chen, Y., Mei, Y. H., Lin, W., et al. (2014). A multidiscipline method of geological survey, seismic profile and gravity measurement applied to fold-and-thrust belt : a case study along the Hutubi River in the northern piedmont of Tianshan. Chin. J. Geophys. 57, 75-87. doi:10.6038/cjg20140108

Chen, S. P., Qi, J. F., Yu, F. S., and Yang, Q. (2007). Deformation charateristics in the southern margin og the Junggar Basin and their controlling factors. Acta Geol. Sin. 81, 151-157.

Chuang, R. Y., Johnson, K. M., Kuo, Y.-T., Wu, Y.-M., Chang, C.-H., and Kuo, L.C. (2014). Active back thrust in the eastern Taiwan suture revealed by the 2013 Rueisuei earthquake: evidence for a doubly vergent orogenic wedge? Geophys. Res. Lett. 41, 3464-3470. doi:10.1002/2014g1060097

Collettini, C., Tesei, T., Scuderi, M. M., Carpenter, B. M., and Viti, C. (2019). Beyond Byerlee friction, weak faults and implications for slip behavior. Earth Planet Sci. Lett. 519, 245-263. doi:10.1016/j.epsl.2019.05.011

Deng, Q., Feng, X., Zhang, P., Xu, X., Yang, X., Peng, S., et al. (2000). Active tectonics of Tian shan. Beijing: Seismological Press.

Deng, Q., Feng, X., Zhang, P., Yang, X., Xu, X., Peng, S., et al. (1999). Reverse fault and fold zone in the Urumqi range-front depression of the northern Tianshan and its genetic mechanism. Earth Sci. Front. 6, 191-201.

Gladwin, M. T., Gwyther, R. L., Hart, R. H. G., and Breckenridge, K. S. (1994). Measurements of the strain field associated with episodic creep events on the san andreas fault at San Juan Bautista, California. J. Geophys. Res. 99, 4559-4565. doi:10.1029/93jb02877

Gong, Z., Jing, Y., Li, H., Li, L., Fan, X., and Liu, Z. (2019). Static-dynamic strain response to the 2016 M6.2 Hutubi earthquake (eastern Tien Shan, NW China) recorded in a borehole strainmeter network. J. Asian Earth Sci. 183, 103958. doi:10.1016/j.jseaes.2019.103958

Guan, S., Stockmeyer, J. M., Shaw, J. H., Plesch, A., and Zhang, J. (2016). Structural inversion, imbricate wedging, and out-of-sequence thrusting in the southern Junggar fold-and-thrust belt, northern Tian Shan, China. Bulletin 100, 1443-1468. doi:10.1306/04041615023

He, P., Hetland, E. A., Niemi, N. A., Wang, Q., Wen, Y., and Ding, K. (2018). The $2016 \mathrm{Mw} 6.5$ Nura earthquake in the Trans Alai range, northern Pamir: possible rupture on a back-thrust fault constrained by Sentinel-1A radar interferometry. Tectonophysics 749, 62-71. doi:10.1016/j.tecto.2018.10.025

Jiang, G., Qiao, X., Wang, X., Lu, R., Liu, L., Yang, H., et al. (2020). GPS observed horizontal ground extension at the Hutubi (China) underground gas storage facility and its application to geomechanical modeling for induced seismicity. Earth Planet Sci. Lett. 530, 115943. doi:10.1016/j. epsl.2019.115943

Johnston, M. J. S., Borcherdt, R. D., Linde, A. T., and Gladwin, M. T. (2006). Seismomagnetic effects from the long-awaited 28 september 2004 M 6.0 parkfield earthquake. Bull. Seismol. Soc. Am. 96, S206-S220. doi:10.1785/ 0120050822

King, G. C., Stein, R. S., and Lin, J. (1994). Static stress changes and the triggering of earthquakes. Bull. Seismol. Soc. Am. 84, 935-953.

Li, Y., Wei, D., Tian, H., Jia, D., Fang, L., Yan, B., et al. (2018). The 3-D structural model of an out-of-sequence earthquake in China: Implication for the reactivation of positive inversion structures along the Northern Tianshan fold-and-Thrust belt. Tectonics 37, 4359-4376. doi:10.1029/2018tc005075

Linde, A. T., Gladwin, M. T., Johnston, M. J. S., Gwyther, R. L., and Bilham, R. G. (1996). A slow earthquake sequence on the San Andreas fault. Nature 383, 65-68. doi:10.1038/383065a0

Liu, B. J., Shen, J., Zhang, X. K., Chen, Y., Fang, S. M., Song, H. P., et al. (2007). The crust structures and tectonics of ürümqi depression revealed by deep seismic reflection profile in the northern margin of tianshan mountains. Chin. J. Geophys. 50, 1464-1472. doi:10.1002/cjg2.1146

Liu, D. Q., Liu, M., Wang, H. T., Li, J., Cheng, J., and Wang, X. Q. (2016). Slip rates and seismic moment deficits on major faults in the Tianshan region. Chin. J. Geophys. 59, 1647-1660. doi:10.6038/cjg20160510

Liu, G., Qiao, X., Xiong, W., Zhou, Y., Nie, Z., and Xia, C. (2017). Source models for the $2016 \mathrm{M}$ w6.0 Hutubi earthquake, Xinjiang, China: a possible reverse event. Geodesy Geodyn. 8, 311-318. doi:10.1016/j.geog.2017.05.005

Liu, J. M., Wang, Q., Li, J., Wu, C. Y., Zhao, B. B., and Kong, X. Y. (2018). Relocation of the Hutubi Ms6.2 earthquake sequence on 8 December 2016 and analysis of the seismogenic structure. Seismol. Geol. 40, 566-578. doi:10.3969/ j.issn.0253-4967.2018.03.005
Lu, R., He, D., Xu, X., Wang, X., Tan, X., and Wu, X. (2018). Seismotectonics of the 2016 M 6.2 Hutubi earthquake: implications for the 1906 M 7.7 Manas earthquake in the Northern Tian Shan Belt, China. Seismol Res. Lett. 89, 13-21. doi:10.1785/0220170123

Martinod, J., Gérault, M., Husson, L., and Regard, V. (2020). Widening of the Andes: an interplay between subduction dynamics and crustal wedge tectonics. Earth Sci. Rev. 204, 103170. doi:10.1016/j.earscirev.2020.103170

Molnar, P., and Tapponnier, P. (1975). Cenozoic tectonics of Asia: effects of a continental collision: features of recent continental tectonics in Asia can be interpreted as results of the India-Eurasia collision. Science 189, 419-426. doi:10.1126/science.189.4201.419

Neil, E. A., and Houseman, G. A. (1997). Geodynamics of the Tarim Basin and the Tian Shan in central Asia. Tectonics 16, 571-584. doi:10.1029/97tc01413

Nykolaishen, L., Dragert, H., Wang, K., James, T. S., and Schmidt, M. (2015). GPS observations of crustal deformation associated with the $2012 \mathrm{Mw} 7.8$ Haida Gwaii earthquake. Bull. Seismol. Soc. Am. 105, 1241-1252. doi:10.1785/0120140177

Okada, Y. (1985). Surface deformation due to shear and tensile faults in a halfspace. Bull. Seismol. Soc. Am. 75, 1135-1154.

Ouyang, Z., Zhang, Z., and Shu, G. L. (2004). Review and outlook for west China borehole strainmeter netorks. Chin. J. Rock Mech. Eng. 23, 4058-4062.

Perfettini, H., Frank, W. B., Marsan, D., and Bouchon, M. (2019). Updip and alongstrike aftershock migration model driven by afterslip: application to the 2011 Tohoku-Oki aftershock sequence. J. Geophys. Res. Solid Earth. 124, 2653-2669. doi:10.1029/2018jb016490

Poblet, J., and Lisle, R. J. (2011). Kinematic evolution and structural styles of fold-and-thrust belts, Geol. Soc., London, Spec. Publ. 349, 1-24. doi:10.1144/ sp349.1

Qiu, J., Rao, G., Wang, X., Yang, D., and Xiao, L. (2019). Effects of fault slip distribution on the geometry and kinematics of the southern Junggar fold-andthrust belt, northern Tian Shan. Tectonophysics 772, 228209. doi:10.1016/j. tecto.2019.228209

Qiu, Z., and Shi, Y. (2003). Observations of remote coseismic stress step-changes. Sci. China Earth Sci. 46, 75-81. doi:10.1360/03dz0007

Qiu, Z., Tang, L., Zhang, B., and Guo, Y. (2013). In situ calibration of and algorithm for strain monitoring using four-gauge borehole strainmeters (FGBS). J. Geophys. Res. Solid Earth. 118, 1609-1618. doi:10.1002/jgrb.50112

Ross, Z. E., Rollins, C., Cochran, E. S., Hauksson, E., Avouac, J.-P., and Ben-Zion, Y. (2017). Aftershocks driven by afterslip and fluid pressure sweeping through a fault-fracture mesh. Geophys. Res. Lett. 44, 8260-8267. doi:10.1002/ $2017 \mathrm{gl} 074634$

Shao, X., Zhang, J., Fan, H., Zheng, J. D., Xu, Y., Zhang, H. Q., et al. (1996). The crust structures of Tianshan orogenic belt: a deep sounding work by converted waves of earthquakes along Urumqi-Korla profile. Chin. J. Geophys. 39, 336-346.

Shen, Z.-K., Sun, J., Zhang, P., Wan, Y., Wang, M., Bürgmann, R., et al. (2009). Slip maxima at fault junctions and rupturing of barriers during the 2008 Wenchuan earthquake. Nat. Geosci. 2, 718-724. doi:10.1038/ngeo636

Stagpoole, V., and Nicol, A. (2008). Regional structure and kinematic history of a large subduction back thrust: Taranaki Fault, New Zealand. J. Geophys. Res.: Solid Earth 113, B01403. doi:10.1029/2007jb005170

Wang, C., Yang, Z. E., Luo, H., and Mooney, W. D. (2004). Crustal structure of the northern margin of the eastern Tien Shan, China, and its tectonic implications for the 1906 M?7.7 Manas earthquake. Earth Planet Sci. Lett. 223, 187-202. doi:10.1016/j.epsl.2004.04.015

Wang, M., and Shen, Z.-K. (2020). Present-day crustal deformation of continental China derived from GPS and its tectonic implications. J. Geophys. Res.: Solid Earth. 125, e2019JB018774. doi:10.1029/2019jb018774

Wang, R., Lorenzo-Martín, F., and Roth, F. (2006). PSGRN/PSCMP-a new code for calculating co- and post-seismic deformation, geoid and gravity changes based on the viscoelastic-gravitational dislocation theory. Comput. Geosci. 32, 527-541. doi:10.1016/j.cageo.2005.08.006

Wang, X., Zhang, J., Jiang, W., Wang, D., Xu, G., Xiao, Z., et al. (2019). Gravity field and deep seismogenic environment in the Longmen Shan and adjacent regions, Eastern Tibetan Plateau. J. Asian Earth Sci. 176, 79-87. doi:10.1016/j.jseaes. 2019.01.011

Wessel, P., Smith, W. H. F., Scharroo, R., Luis, J., and Wobbe, F. (2013). Generic mapping tools: improved version released. Eos Trans. AGU. 94, 409-410. doi:10.1002/2013eo450001 
Xiao, W.-J., Zhang, L. C., Qin, K. Z., Sun, S., and Li, J. L. (2004). Paleozoic accretionary and collisional tectonics of the Eastern Tianshan (China): implications for the continental growth of central Asia. Am. J. Sci. 304, 370-395. doi:10.2475/ajs.304.4.370

Xu, Z.-Q., Dilek, Y., Yang, J.-S., Liang, F.-H., Liu, F., Ba, D.-Z., et al. (2015). Crustal structure of the Indus-Tsangpo suture zone and its ophiolites in southern Tibet. Gondwana Res. 27, 507-524. doi:10.1016/j.gr.2014.08.001

Xu, Z. G., Liang, S. S., Zou, L. Y., and Liu, J. G. (2019). Mechanism of the 2016 Hutubi, Xinjiang, Ms6.2 mainshock and relocation of its aftershock sequences. Seismol. Geol. 41, 44-57. doi:10.3969/j.issn.0253-4967.2019. 01.003

Yang, S., Li, J., and Wang, Q. (2008). The deformation pattern and fault rate in the tianshan mountains inferred from GPS observations. Sci. China Ser. D-Earth Sci. 51, 1064-1080. doi:10.1007/s11430-008-0090-8

Yang, W., Cheng, J., Yao, Q., Cui, R. S., Long, H. Y., and Han, Y. Y. (2018). The preliminary study on the seismogenic structure of the Hutubi Ms6.2 earthquake. Seismol. Geol. 40, 1100-1114.

Yang, X., Li, A., and Hunag, W. (2013). Uplift differential of active fold zones during the late quaternary, northern piedmonts of the tianshan mountains, China. Sci. China Earth Sci. 56, 794-805. doi:10.1007/s11430-012-4531-z

Yang, Y. H., Hu, J. C., Chen, Q., Wang, Z. G., and Tsai, M. C. (2019). A blind thrust and overlying folding earthquake of the $2016 \mathrm{Mw}$ 6.0 Hutubi earthquake in the Northern Tien Shan fold-and-thrust belts, China. Bull. Seismol. Soc. Am. 109, 770-779. doi:10.1785/0120180150

Yin, A., Nie, S., Craig, P., Harrison, T. M., Ryerson, F. J., Xianglin, Q., et al. (1998). Late Cenozoic tectonic evolution of the southern Chinese Tian Shan. Tectonics 17, 1-27. doi:10.1029/97tc03140

Zelilidis, A., Papatheodorou, G., Maravelis, A. G., Christodoulou, D., Tserolas, P., Fakiris, E., et al. (2016). Interplay of thrust, back-thrust, strike-slip and salt tectonics in a fold and thrust belt system: an example from Zakynthos Island, Greece. Int. J. Earth Sci. 105, 2111-2132. doi:10.1007/s00531-0161299-y
Zhang, P., Deng, Q., Yang, X., Peng, S., Xu, X., and Feng, X. (1996). Late cenozoic tectonic deformation and mechanism along the tianshan mountain, northwestern China. Earthq. Res. China. 12, 127-140.

Zhang, P., Deng, Q., Zhang, G., Ma, J., Gan, W., Min, W., et al. (2003). Active tectonic blocks and strong earthquakes in the continent of China. Sci. China Earth Sci. 46, 13-24. doi:10.1360/03dz0002

Zhang, P. Z., Deng, Q. D., Xu, X. W., Feng, X. Y., Peng, S. Z., Yang, X. P., et al. (1994). Blind thrust, folding earthquake, and the 1906 Manas earthquake, Xinjing. Seismol. Geol. 16, 193-204.

Zhang, Z., Zhang, H., Wang, L., Cheng, H., and Shi, Y. (2019). Late cenozoic structural deformation and evolution of the central-southern Longmen Shan fold-and-thrust belt, China: insights from numerical simulations. J. Asian Earth Sci. 176, 88-104. doi:10.1016/j.jseaes.2019.01.026

Zhou, Y., Wu, C., Yuan, B., Wang, J., Zhou, T., Wang, Y., et al. (2020). Cenozoic tectonic patterns and their controls on growth strata in the northern Tianshan fold and thrust belt, northwest China. J. Asian Earth Sci. 198, 104237. doi:10. 1016/j.jseaes.2020.104237

Zubovich, A. V., Wang, X. Q., Scherba, Y. G., Schelochkov, G. G., Reilinger, R., Reigber, C., et al. (2010). GPS velocity field for the Tien Shan and surrounding regions. Tectonics 29, TC6014. doi:10.1029/2010tc002772

Conflict of Interest: The authors declare that the research was conducted in the absence of any commercial or financial relationships that could be construed as a potential conflict of interest.

Copyright (c) 2020 Li, Zhang, Tang, Chen and Jing. This is an open-access article distributed under the terms of the Creative Commons Attribution License (CC BY). The use, distribution or reproduction in other forums is permitted, provided the original author(s) and the copyright owner(s) are credited and that the original publication in this journal is cited, in accordance with accepted academic practice. No use, distribution or reproduction is permitted which does not comply with these terms. 